\title{
Leguminous species effect in agroforestry systems in the Portuguesa state. Venezuela
}

\section{Efecto de especies leguminosas en sistemas agroforestales en el Estado Portuguesa. Venezuela}

ORTEGA-RAMIREZ, Marynor Elena $\dagger^{*}$, CASTRO-OSORIO, Adrian, GONZALEZ-CORTÉS, Nicolás and PRADOS-CORONADO, Jesús

Universidad Autónoma de Chiapas, Mayan Faculty of Agricultural Studies, Catazaja, Chiapas, México, C.P. 29980

ID $1^{\text {st }}$ Author: Marynor Elena, Ortega-Ramírez / ORC ID: 0000-0002-2551-4054, Researcher ID Thomson: S-4732-2018, CVU CONACYT ID: 446579

ID $1^{\text {st }}$ Coauthor: Adrian, Castro-Osorio / ORC ID: 0000-0003-2873-9467

ID $2^{\text {nd }}$ Coauthor: Nicolás, Gonzáles-Cortés / ORC ID: 0000-0001-7336-4524, CVU CONACYT ID: 123381

ID $3^{\text {rd }}$ Coauthor: Jesús, Prados-Coronado / ORC ID: 0000-0003-4306-9895

DOI: $10.35429 /$ EJE.2020.13.7.31.37

Received July 14, 2020; Accepted December 30, 2020

\begin{abstract}
Six leguminous species Frijol bayo (Vigna unguiculata), Frijol white Var. Orituco, Quinchoncho dwarf (Cajanus cajan (L.) Millsp., cv. Aroita), Kudzú tropical (Pueraria phaseoloides), Crotalaria (Crotalaria juncea), Sesbania (Sesbania grandiflora) were established in an agroforest systems to assess his effect on the chemical property of a Alfisol soil at municipality Ospino Portuguese state, at the farm La Yaguara planted with $E$. urograndis. In a design in random blocks with 7 processings and 4 repetitions, employing STATIXTIS 9.0 to carry out the ANDEVA and for variables where differences are presented the test was employed of Tukey (5\%); obtaining as results that in the soil of the farm The Yaguara alone significant differences were found $(\mathrm{P}<0,05)$ for the variables relation $\mathrm{C} / \mathrm{N}, \mathrm{CO}$, $\mathrm{Zn}$, highly significant and differences $(\mathrm{P}<0,01)$ for $\mathrm{N}$; being the Sesbania and quinchoncho the best treatment in relation $\mathrm{C} / \mathrm{N}$; for $\mathrm{CO}$ the frijol blanco and the treatment control; for $\mathrm{Zn}$ the quinchoncho and treatment control, frijol blanco and kudzú tropical; in the $\mathrm{N}$ quinchoncho and Sesbania. To confirm the generated profit to the agroforestry system analysis were completed foliate to the eucalyptus, finding highly significant differences for $\mathrm{P}$ with Frijol blanco and Kudzú and significant for $\mathrm{Zn}$ where is quinchoncho and treatment control.
\end{abstract}

Leguminous, Agroforest, Eucalyptus, Green compost

\begin{abstract}
Resumen
Seis especies leguminosas frijol bayo (Vigna unguiculata), frijol blanco Var. Orituco, Quinchoncho enano (Cajanus cajan (L.) Millsp., cv. Aroita), Kudzú tropical (Pueraria phaseoloides), Crotalaria (Crotalaria juncea), Sesbania (Sesbania grandiflora) fueron establecidas en un sistema agroforestal para evaluar su efecto sobre las propiedades químicas de un suelo alfisol en el municipio Ospino estado Portuguesa, en la Finca La Yaguara plantada con E. urograndis. En un diseño en bloques al azar con 7 tratamientos y 4 repeticiones, se utilizó STATIXTIS 9.0 para realizar el ANDEVA y empleó la prueba de Tukey (5\%); Los resultados indican que en la finca La Yaguara se encontraron diferencias $(\mathrm{P}<0,05)$ para las variables relación $\mathrm{C} / \mathrm{N}, \mathrm{CO}, \mathrm{Zn}$, y cambios altamente significativas $(\mathrm{P}<0,01)$ para N; y al comparar medias la Sesbania y el quinchoncho fueron del mejor grupo en relación $\mathrm{C} / \mathrm{N}$; para $\mathrm{CO}$ el frijol blanco y el tratamiento testigo; para $\mathrm{Zn}$ el quinchoncho, frijol blanco y kudzú tropical; mientras que para el $\mathrm{N}$ quinchoncho fue el mejor tratamiento. Para constatar el beneficio generado al sistema agroforestal se realizaron análisis foliares al eucalipto, encontrándose diferencias altamente significativas para $\mathrm{P}$ en los tratamientos con Frijol blanco y Kudzú y significativas para $\mathrm{Zn}$ en donde se estableció quinchoncho.
\end{abstract}

Leguminosa, Agroforestal, Eucalyptus, Abono verde

Citation: ORTEGA-RAMIREZ, Marynor Elena, CASTRO-OSORIO, Adrian, GONZALEZ-CORTÉS, Nicolás and PRADOS-CORONADO, Jesús. Leguminous species effect in agroforestry systems in the Portuguesa state. Venezuela. ECORFAN Journal-Ecuador. 2020. 7-13:31-37.

\footnotetext{
*Correspondence to Autor (E-mail: marynor.ortega @gmail.com)

$\dagger$ Researcher contributing as first author.
} 


\section{Introduction}

In the search for sustainable production systems, especially for tropical areas where socioeconomic problems added to those of high susceptibility to erosion and low soil fertility produce significant losses in productivity, agroforestry systems appear to be advantageous in the short and long term., especially for the contribution of organic matter and nutrients through the tree component (Ramírez 2000).

Considering all the advantages and benefits generated by the use of legume species, together with the profitability and sustainability of forest systems; It is interesting to evaluate the effects of the establishment of agroforestry systems with legume species on the chemical properties of an Alfisol soil in the Ospino municipality, Portuguesa state. This allows generating local information that is applicable to soils with similar characteristics, where income can be obtained from the economic point of view in the short, medium and long term, maintaining the ecological balance and the sustainable management of natural resources. In addition, given the sustainable use of soil resources and the management of sustainable commercial plantations, this type of strategies helps to reduce the use of agrochemicals, food production in agroforestry crops, Mulch incorporation among other benefit0073NM .

\section{Methodology}

\section{Study area}

The test was established in the La Yaguara farm under forest exploitation, the agroecological system that is presented is at an altitude between 170 and 210 meters above sea level; with an almost flat relief and the highest proportion of soils between slopes of 0 to 3\%. The La Yaguara farm, planted with Eucalyptus urograndis, is owned by the company Forestal SMURFITKAPPA - REFORESTADORA DOS REFORDOS CA, a subsidiary of Cartón de Venezuela located in the Ospino municipality of the Portuguese state.

\section{Experimental design}

A randomized block design was established with 7 treatments and 4 repetitions, where the treatments were made up of the different legume species established in the street of two threads of the forest species by repetition and each one constituted by 6 forest plants per thread; with an area of $54 \mathrm{~m} 2$ per repetition, for a total test area of $1512 \mathrm{~m} 2$; where:

$\mathrm{T} 0=$ Control (Forest species without legumes on the street)

$\mathrm{T} 1=$ Bayo Bean $\mathrm{T} 2=$ White Bean $\mathrm{T} 3=$ Dwarf Quinchoncho $=$ Sesbania

T4 = Tropical Kudzú T5 = Crotalaria T6

\section{Chemical determination of the soil}

4 composite samples were taken at different depths 0-20 cm; 20-40 cm and 40-60 cm; before establishing the forest plantation and then 15 days after the establishment of the forest plantation and associated legumes. The samples were analyzed by EDAFOFINCA where analysis methods are used for fertilization purposes: Texture: distribution and particle size (Bouyoucos) * pH (Soil-water ratio: 1: 2.5) *; Phosphorus (Olsen, 1954) *; Potassium (Olsen,) *; Calcium (Morgan) *; organic matter (OM; Moisture combustion, modified Walkey and Black) *; Exchangeable aluminum, (extracted with $0.5 \mathrm{M} \mathrm{BaCl} 2$ ratio $1: 10) *$ and $\mathrm{EC}(\mathrm{mS} / \mathrm{cm}$ $25^{\circ} \mathrm{C}$ conductimeter). A database was created with the information provided by the analyzes and statistical analysis was used as a tool to determine possible differences in the system.

\section{Quantification of the nutritional quality of the forest species during the association}

The elements determined in the foliar analysis were: N, P, K, Ca, Mg, Fe, Cu, Zn and Mn. The nutritional content of the foliar samples allowed for statistical analysis and comparisons that allowed identifying the legume that provides substantial improvements to the system or determining whether there are changes. 


\section{Statistic analysis}

In the statistical analysis, a database was elaborated and it was analyzed with STATIXTIS 9.0 to perform the analysis of variance (ANDEVA) and for the comparison of means between the variables where differences are present, the Tukey test at $5 \%$ was used.

\section{Results}

Table 1 shows initial characteristics of the soil of the La Yaguara farm (lot 16) planted with Eucalyptus urograndis, where $\mathrm{pH}$ between 5.5 6.5 , normal or non-saline $\mathrm{EC}$, medium to low $\mathrm{CO} \%$ stands out. , $\mathrm{N}$ at low levels, $\mathrm{C} / \mathrm{N}$ ratio, $\mathrm{P}$, $\mathrm{K}, \mathrm{Fe}$ and $\mathrm{Cu}$ at medium levels and very high values for the elements $\mathrm{Ca}, \mathrm{Mg}, \mathrm{Zn}$ and $\mathrm{Mn}$.

\begin{tabular}{|l|r|r|r|r|}
\hline \multicolumn{1}{|c|}{ PTO } & \multicolumn{1}{c}{$\mathbf{2}$} & \multicolumn{1}{c|}{$\mathbf{3}$} & \multicolumn{1}{c|}{} \\
\hline PH & 6,05 & 5,88 & 6,11 & 5,4 \\
\hline ECmS/cm & 0,06 & 0,1 & 0,04 & 0,07 \\
\hline CO\% & 1,93 & 1,37 & 0,92 & 1,84 \\
\hline N\% & 0,157 & 0,114 & 0,081 & 0,125 \\
\hline Relationship C/N & 12,3 & 12 & 11,4 & 14,7 \\
\hline P** & 17 & 14 & 11 & 7 \\
\hline $\mathrm{K}^{* *}$ & 115 & 150 & 95 & 70 \\
\hline $\mathrm{Ca}^{*}$ & 14,85 & 11,35 & 10,25 & 12 \\
\hline $\mathrm{Mg}^{*}$ & 3,21 & 3,44 & 4,85 & 2,88 \\
\hline $\mathrm{Fe}^{*}$ & 33 & 66 & 93 & 53 \\
\hline $\mathrm{Cu}^{*}$ & 1 & 2 & 2,8 & 2,2 \\
\hline $\mathrm{Zn}^{*}$ & 11,5 & 5,2 & 4,6 & 5,5 \\
\hline $\mathrm{Mn}^{*}$ & 155 & 97 & 165 & 94 \\
\hline
\end{tabular}

Table 1 Initial soil characteristics of the La Yaguara farm (lot 16) planted with Eucalyptus urograndis Source: EDAFOFINCA Analysis - Own Data $*=\operatorname{cmol}(+) K^{-1}$ $* *=m g / l t$

The initial values of elements determined in foliar samples of the established forest species are shown, which when compared with the values and deficient for Eucalyptus species at the foliar level presented by Ortiz C. and Salamanca V. (2018) based on Aparicio (2001), the macronutrient values $(\mathrm{N}(2.77 \%), \mathrm{P}(0.2), \mathrm{K}$ (1.2), Ca (1.15), Mg (0.24) and S (0.2) present values very low, close to or below the deficiency limits; while for microelements such as Fe (310 mg / I), Cu (12), Zn (36) and Mn (114), the values are within the ranges adequate or above these. Which indicates that there is an obvious lack of nutrients in the soil, so contributions must be made via chemical fertilization.

\section{Trial established at the La Yaguara farm}

Table 2 shows the analysis of variance (ANDEVA), $F$ values and their degree of significance, showing significant differences $(\mathrm{P}$ $<0.05 \%)$ for the variables carbon-nitrogen ratio $(\mathrm{C} / \mathrm{N})$, phosphorus ( P), Organic Carbon (C0) and Zinc $(\mathrm{Zn})$, with a coefficient of variation (CV) of $5.15 ; 12.29 ; 5.5$; and $12.87 \%$ respectively; which indicates that the design used was adequate.

For the nitrogen variable $(\mathrm{N})$, a highly significant behavior $(\mathrm{P}<0.01)$ was found among the treatments with a variation coefficient of $7.12 \%$, which indicates that the experimental design and the statistical analysis used are the most appropriate. This coincides with what was obtained by UNAL (2005), Arteaga et al., (2016), Luciana (2016), where significant changes were observed in the elements specifically analyzed in relation to $\mathrm{C} / \mathrm{N}, \mathrm{CO}$ and nitrogen when studying the effect of different legumes.

\begin{tabular}{|l|r|r|l|}
\hline $\begin{array}{c}\text { Variation } \\
\text { Source }\end{array}$ & Treatment & $\begin{array}{c}\text { CV } \\
(\%)\end{array}$ & Significance \\
\hline $\mathrm{C} / \mathrm{N}$ & 2,83 & 5,15 & $*$ \\
\hline $\mathrm{EC}(\mathrm{mS} / \mathrm{cm})$ & 2,32 & 21,66 & n.s \\
\hline $\mathrm{CO}(\%)$ & 2,89 & 5,5 & $*$ \\
\hline $\mathrm{Cu}(\mathrm{mg} / \mathrm{l})$ & 0,90 & 12,99 & n.s \\
\hline $\mathrm{Fe}(\mathrm{mg} / \mathrm{l})$ & 1,59 & 13,44 & n.s \\
\hline $\mathrm{K}(\mathrm{mg} / \mathrm{l})$ & 1,13 & 11,93 & n.s \\
\hline $\mathrm{Mn}(\mathrm{mg} / \mathrm{l})$ & 0,82 & 20,9 & n.s \\
\hline $\mathrm{N}(\%)$ & 5,07 & 7,12 & $* *$ \\
\hline $\mathrm{P}(\mathrm{mg} / \mathrm{l})$ & 1,66 & 12,29 & n.s \\
\hline $\mathrm{Zn}(\mathrm{mg} / \mathrm{l})$ & 2,92 & 12,87 & $*$ \\
\hline
\end{tabular}

Table 2 ANDEVA (Value of $F$ and degree of significance) for the variables analyzed in the Finca La Yaguara, Ospino municipality of the Portuguese State

Degree of significance: * significant differences $(\mathrm{P}<0.05)$, $* *$ highly significant differences $(\mathrm{P}<0.01)$, n.s. There are no significant differences

Source: own calculations

The previous table shows the comparison of means analyzed, where it is observed that in the variable Carbon / Nitrogen $(\mathrm{C} / \mathrm{N})$ ratio, two homogeneous groups were formed, where the best group (a) is constituted by treatment 6 with 18, 20 for the Sesbania species, and a second group formed by treatment 3 (group b) that corresponds to the association with quinchoncho with 15.75, which coincides with the results obtained by UNAL (2005) whose initial values of the $\mathrm{C}$ relation / $\mathrm{N}$ was similar for all species and fluctuated between 9.4 and 13 . 
Regarding the percentage of $\mathrm{CO}$, two homogeneous groups were formed consisting of treatment 2 (group a) corresponding to white beans with $2.15 \%$ and group $b$ formed by the control treatment (T0) without legume species with $2.10 \%$. In a similar way, but with other legume species Rivero (1997) in a study carried out under greenhouse conditions, the result was significant differences with an increase in $\mathrm{CO}$ in all treatments, where the treatment responsible for the highest $\mathrm{CO}$ values was crotalaria, even when not statistically differentiated from the mix. Paolini (2017) mentions the importance of organic agriculture, presenting the highest total organic carbon values, mentioning that organic production is a sustainable management system.

The cation exchange capacity increases as a function of the increase in organic matter and thus the bioavailability of other important elements such as phosphorus may improve and the toxicity of other elements may be inhibited by the formation of chelates or other bonds, for example, aluminum and organic matter. Similarly, for the element nitrogen $(\mathrm{N}), 2$ homogeneous groups were formed, where the best group (a) consisted of treatment 3 (quinchoncho) with $0.1325 \%$ and a group C formed by treatment 6 with the species Sesbania with $0.1048 \%$, while the rest of the treatments formed heterogeneous groups with intermediate values between group a and c.

Even though the best species in our case did not turn out to be crotalaria, within the trial carried out by Ojeda (2019) with the aim of selecting effective species of arbuscular mycorrhizal fungi in the Crotalaria juncea species, used as green manure, it presented a fundamental aspect in the decomposition of green manures in the soil is its carbon / nitrogen ratio, which indicates the feasibility of using this legume as green manure to improve the soil in areas destined for production.

In Table 3 of comparison of means for the nitrogen variable in the Yaguara farm, the best group was made up of the treatment with quinchoncho associated with Eucalyptus (treatment 3), this coincides with Torres et al., (2018) mention that agroecological techniques are a viable alternative to improve soil fertilization, generating suppression for weeds, conservation of soil nutrients $\mathrm{N}, \mathrm{P}, \mathrm{K}$, thus increasing ecological and economic benefits.

\begin{tabular}{|r|r|r|r|r|}
\hline Treatment & \multicolumn{1}{c}{$\mathbf{C} / \mathbf{C}$} & $\mathbf{N}$ & $\mathbf{Z n}$ \\
\hline 0 & $16,82 \mathrm{ab}$ & $2,10 \mathrm{~b}$ & $0,1170 \mathrm{abc}$ & $2,85 \mathrm{~b}$ \\
\hline 1 & $16,72 \mathrm{ab}$ & $2,00 \mathrm{ab}$ & $0,1283 \mathrm{ab}$ & $3,50 \mathrm{ab}$ \\
\hline 2 & $16,95 \mathrm{ab}$ & $2,15 \mathrm{a}$ & $0,1218 \mathrm{abc}$ & $2,85 \quad \mathrm{~b}$ \\
\hline 3 & $15,75 \mathrm{~b}$ & $2,08 \mathrm{ab}$ & $0,1325 \mathrm{a}$ & $5,05 \mathrm{a}$ \\
\hline 4 & $16,92 \mathrm{ab}$ & $1,89 \mathrm{ab}$ & $0,1122 \mathrm{bc}$ & $2,80 \quad \mathrm{~b}$ \\
\hline 5 & $16,75 \mathrm{ab}$ & $1,92 \mathrm{ab}$ & $0,1150 \mathrm{abc}$ & $3,10 \mathrm{ab}$ \\
\hline 6 & $18,20 \mathrm{a}$ & $1,91 \mathrm{ab}$ & $0,1048 \quad \mathrm{c}$ & $3,30 \mathrm{ab}$ \\
\hline
\end{tabular}

Table 3 Comparison of means for the variables analyzed at Finca La Yaguara, Ospino municipality of the Portuguese State

a, b, c: significantly different homogeneous groups

Source: own calculations

Analyzing the results obtained in the $\mathrm{C} /$ $\mathrm{N}, \mathrm{CO}$ and $\mathrm{N}$ relationship, Rivero and Paolini (1995) mention that the effect achieved has been pointed out by many researchers such as: Wade and Sánchez (1983), Heng and Goh (1984), Clay and Clapp (1990), Costa et al., (1990), Duxbury et al., (1991); Prasad et al., (1991) and is due, in the case of nitrogen, to the content of this element in incorporated tissues and its subsequent mineralization. Regarding the $\mathrm{C} / \mathrm{N}$ relationship, due to the values presented by the legumes under study, the quinchoncho, the white beans and the bay beans are presented as a good option to improve soils in the short term.

While Sesbania due to its high $\mathrm{C} / \mathrm{N}$ ratio would be very useful if you want to maintain the nitrogen supply in the soil more slowly and for a longer duration. For the variable Zinc (Zn), since there were significant differences in the previous table of comparison of means, it is observed that two homogeneous groups were formed, consisting of treatment 3 (group a) with quinchoncho, mean of $5.05 \mathrm{mg} / 1$ and the group b with treatments 0.2 and 4 (control, white beans and tropical kudzu) with a mean of $2.85 ; 2.85$ and $2.80 \mathrm{mg} / 1$ respectively.

Castro (2017) mentions that the annual legume species of rapid establishment, high biomass production and tolerance to drought are an alternative to be used as green manures. Higuera et al., (2001), where they determined the effect of cutting height and age on the mineral content of the elements $\mathrm{P}, \mathrm{K}, \mathrm{Ca}, \mathrm{Na}$, $\mathrm{Mg}, \mathrm{Zn}$ and $\mathrm{Mn}$, in leaves and stems of quinchoncho Cajanus cajan (L.) Millsp; found significant differences $(\mathrm{P}<0.01)$ between varieties for the elements $\mathrm{P}, \mathrm{K}, \mathrm{Mg}, \mathrm{Zn}$ and $\mathrm{Mn}$. Where there was also a differential response in cutting heights for all elements $(\mathrm{P}<0.01)$, except for Na. 
All the elements varied in concentration during the cutting ages except for phosphorus, which tended to remain constant. The high $\mathrm{Zn}$ content in the quinchoncho could be the source to increase the existing values in the soil and given the $\mathrm{C} / \mathrm{N}$ ratio of the quinchoncho, it can be easily decomposed and provide all the elements available in the plant in leaves, roots and stems. In this particular Ratto and Miguez (S.f.), indicate that nitrogen fertilization or the incorporation of organic matter in the soil, promotes the absorption of $\mathrm{Zn}$ by the plant, although the most common is to find $\mathrm{Zn}$ deficiencies due to excesses of $P$.

\section{Quantification of the nutritional quality of the forest species during the association. farm la yaguara}

To determine the nutritional quality of the forest species, the analysis of variance (ANDEVA), F values and their degree of significance for the variables analyzed 10 months after establishing the trial with legume species are shown. There were highly significant differences $(\mathrm{P}<0.01)$ for the element phosphorus $(\mathrm{P})$ with a coefficient of variation of $13.61 \%$ and significant differences ( $\mathrm{P}<0.05$ ) for the element $\mathrm{Zn}$ with a coefficient of variation of $17,10 \%$, which indicates that the experimental design and the analysis carried out are adequate for the variables measured in the trial.

Table 4 shows the comparison of means for the variables analyzed in the foliar samples of Eucalyptus urograndis, it is observed that for the element phosphorus (P) two homogeneous groups were formed where group a was constituted by treatment 1 corresponding to bay beans with $0.1725 \mathrm{mg} / 1$.

\begin{tabular}{|r|r|r|} 
Treatment & \multicolumn{1}{c|}{$\mathbf{P}(\%)$} & $\mathbf{Z n}(\mathbf{m g} / \mathbf{l})$ \\
\hline 0 & $0,1225 \mathrm{~b}$ & $11,75 \mathrm{~b}$ \\
\hline 1 & $0,1725 \mathrm{a}$ & $18,00 \mathrm{a}$ \\
\hline 2 & $0,1475 \mathrm{ab}$ & $3,25 \mathrm{ab}$ \\
\hline 3 & $0,1500 \mathrm{ab}$ & $18,00 \mathrm{a}$ \\
\hline 4 & $0,1275 \mathrm{~b}$ & $13,50 \mathrm{ab}$ \\
\hline 5 & $0,1200 \mathrm{~b}$ & $14,25 \mathrm{ab}$ \\
\hline 6 & $0,1200 \mathrm{~b}$ & $14,70 \mathrm{ab}$ \\
\hline
\end{tabular}

Table 4 Comparison of means for the variables $\mathrm{P}$ and $\mathrm{Zn}$ in the samples of Foliares in the Finca La Yaguara, Ospino municipality of the Portuguese state

a, b, c: significantly different homogeneous groups

Source: own calculations
For the variable zinc ( $\mathrm{Zn})$, two homogeneous groups were formed where the best group (a) is made up of treatments 3 and 1 of the legumes quinchoncho and beans bayo respectively with $18 \mathrm{mg} / 1$ of $\mathrm{Zn}$ on average.

Trends of the variables $\mathbf{p H}$, electrical conductivity and nitrogen in the soil of the farms under study

$-\mathbf{p H}$

Graphic 1 shows how in the La Yaguara farm, only treatment 2 and 6 increased the $\mathrm{pH}$ by \pm 0.3 units, while the rest of the treatments decreased it between 0.05 and 0.2 units; being treatments 4 and 5 they lowered them less units $(<0.05)$ of $\mathrm{pH}$. This information allows defining the legume species to be established according to the needs of the forest species to be established. At an operational level, the ideal is to use species that help maintain the $\mathrm{pH}$ in the case of the soils of the Yaguara that are between 5.6 and 6 .

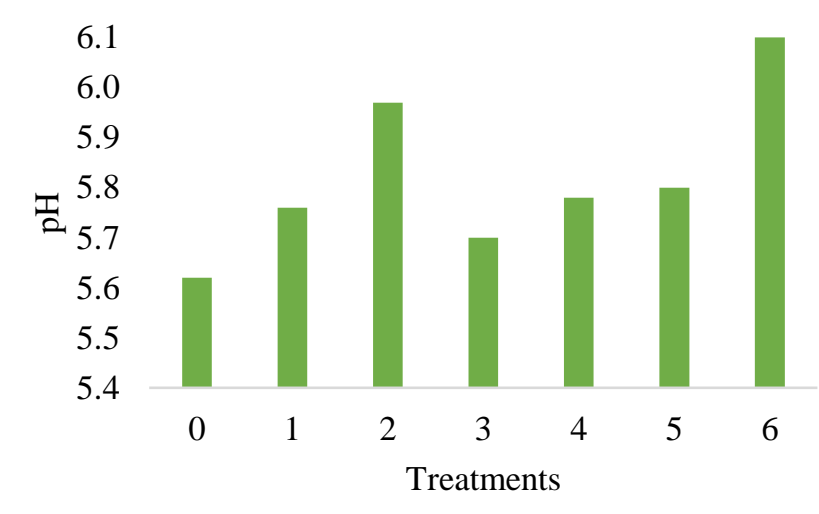

Graphic $1 \mathrm{pH}$ of the soil at the beginning and end of the treatment trial at La Yaguara farm

Source: own calculations

\section{- $\quad$ Electrical Conductivity (EC)}

In the La Yaguara farm (Graphic 2) it is observed how treatment 2 kept the EC stable, when the rest of the treatments decreased it between 0.1 and $0.04 \mathrm{mS} / \mathrm{cm}$. 


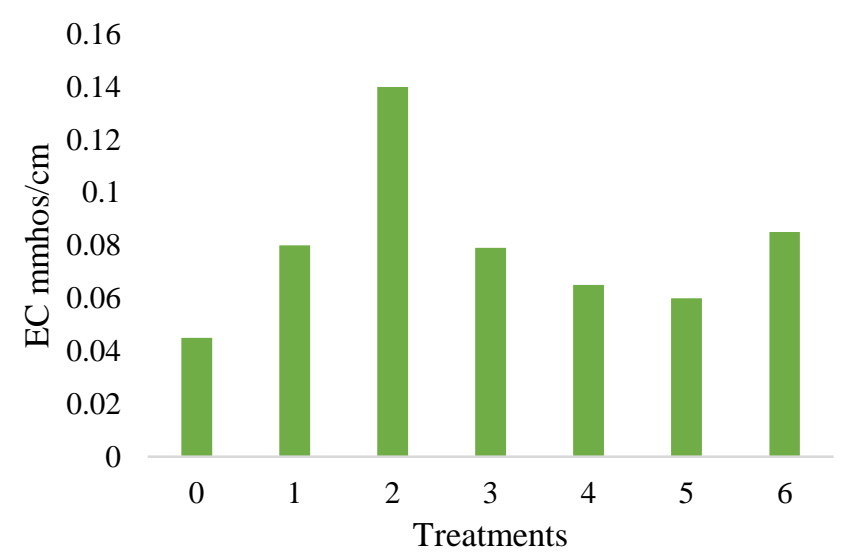

Graphic 2 Electrical conductivity (EC) of the soil at the beginning and end of the treatment trial at La Yaguara farm

Source: own calculations

\section{- Nitrogen}

Graphic 3 shows the changes generated in the test established in the La Yaguara farm, due to the association with leguminous species of the forest species, where treatment 1 (bay beans) and 3 (Quinchoncho) increased the nitrogen content. and treatment 2 (white beans) maintained it. Castro et al., (2018) mention that the species Vigna unguiculata has been evaluated as green manure in an agricultural system which has allowed to obtain an average of 60 to $300 \mathrm{~kg}$ of $\mathrm{N} / \mathrm{ha}$. However, treatments 4, 5, 6 and the control, decreased $\mathrm{N}$ by $0.02 \%$, which allows defining legume species of interest and chemical fertilization plans necessary according to the legume species that is established.

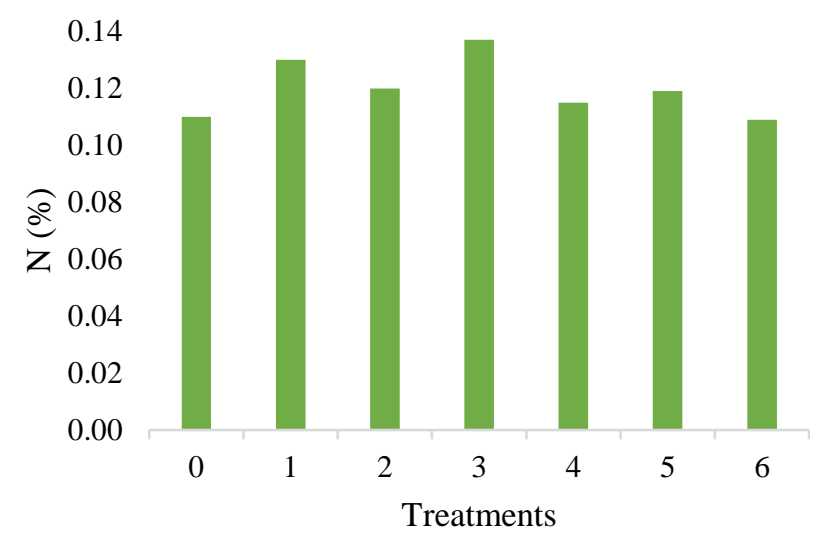

Graphic 3 Percentage of total soil nitrogen at the beginning and end of the trial by treatment at La Yaguara farm

Source: own calculations

\section{Conclusions and recommendations}

The establishment of legume species in agroforestry systems generates significant changes in the chemical properties of an Alfisol soil in the Ospino municipality in the Portuguese state. In the soil of the Yaguara farm, the variables in which the greatest chemical changes occurred in the soil were in the levels of the $\mathrm{C} /$ $\mathrm{N}, \mathrm{CO}, \mathrm{N}$ and $\mathrm{Zn}$ ratio.

During the association, nutritional changes were presented in Eucalyptus at the level of important macroelements such as $\mathrm{P}$ and microelements such as $\mathrm{Zn}$. The legume species that provide the best benefits to the soil and to forest plantations are the Quinchoncho, the white bean and the bayo bean in the short term; and in the long term Sesbania.

The $\mathrm{pH}$ condition of the soils of the La Yaguara farm favored the expression of the changes produced during the association. Although in most of the variables measured in the trial there were no statistical differences between the treatments, visually and numerically improvements were observed in the chemical properties of the soil and the forest species. It is recommended to establish legume species for two consecutive cycles to obtain greater changes in the levels of nitrogen, phosphorus, potassium and zinc.

For future trials, it is recommended to determine the nutritional content of the legume species to be associated, to quantify the contributions to the soil and to the forest species.

Considering that the growth rate of forest species is lower than that of legumes, it is desirable to increase the sowing distance between the forest species and legumes to avoid competition.

\section{References}

Aparicio, J. (2001). Rendimiento y biomasa de Eucalyptus nitens con alternativas nutricionales para una silvicultura sustentable en un suelo rojo arcilloso. Valdivia: Universidad Austral de Chile. Recuperado de http://www.ipef.br/servicos/teses/arquivos/apari cio,jl.pdf 
ARTEAGA, J.; NAVIA, J.; CASTILLO, J. 2016. Comportamiento de variables químicas de un suelo sometido adistintos usos, departamento de Nariño, Colombia. Rev. Cienc. Agr. 33(2):62-75.

http://dx.doi.org/10.22267/rcia.163302.53.

Castro Rincon, E., Mojica Rodríguez, J. E., Carulla Fornaguera, J. E., \& Luscano Aguilar, C. E. (2018). Abonos verdes de leguminosas: integración en sistemas agrícolas y ganaderas del trópico. Universidad de Costa Rica, 711-729.

Castro, R.E.; Sierra, A.; Mojica, J.E.; Carulla, J.E.; Lascano, C.E. Efecto de especies y manejo de abonos verdes de leguminosas en la producción y calidad de un cultivo forrajero utilizado en sistemas ganaderos del trópico seco Archivos de Zootecnia, vol. 66, núm. 253, 2017, pp. 99-106 Universidad de Córdoba Córdoba, España.

Facultad de Agronomía, Universidad de la República, 2015. Fósforo. Curso de Fertilidad de suelos. Disponible en:www.fagro.edu.uy/ fertilidad/publica/tomo_ P_completo1.pdf

Luciana Alcaraz, M. (2016). Liberación/mineralización de nitrógeno y fósforo en hojarasca de Eucalyptus grandis y leguminosas herbáceas en distintos suelos: relación con la calidad física y química del residuo, y efecto sobre el crecimiento de plantas jóvenes de eucalipto. San Francisco de Asís: Facultad de Ciencias Naturales y Museo Universidad Nacional de La Plata.

Ojeda Quintana, L. J., Hernández Vilches, M. E., Sánchez Cordero, L., \& Sainz Lombó, R. (2019). Respuesta de Cro $\neg$ talaria juncea (L.) a la inoculación con especies de hongos micorrízico arbusculares en un suelo pardo grisáceo. Revista Científica Agroecosistemas, 7(2), 23-30 Recuperado de https://aes.ucf.edu.cu/index.php/aes.

Ortiz Calderón, T. A., \& Salamanca Villamarin, L. C. (2018). Extracción de nutrientes y parámetros productivos de Eucalyptus globulus bajo diferentes. Málaga: Universidad Industrial de Santander Instituto De Proyección Regional y Educación a Distancia-IPRED.
Paolini Gómez, J. E. 2017. Actividad microbiológica y biomasa microbiana en suelos cafetaleros de los Andes venezolanos. Terra Latinoamericana 36: 13-22. DOI: https://doi.org/10.28940/terra.v36i1.257

Torres Calderon, S., Huaraca Fernandez, J., Laura Pezo, D., \& Crisóstomo Calderon, R. (2018). Asociación de cultivos, maíz y leguminosas para la conservación de la fertilidad del suelo. Ciencia, Tecnología y Desarrollo, 1522 